\title{
I.M. Гаврищ
}

\section{КОРЕКЦІЯ ПЕЧІНКОВОЇ ЕНЦЕФАЛОПАТІЇ У ХВОРИХ НА ЦИРОЗ ПЕЧІНКИ У ПОСДНАННІ 3 ДИСБІОЗОМ КИШЕЧНИКУ}

\author{
ДВНЗ «Івано-Франківський національний медичний університет»
}

Резюме. Обстежено 65 хворих на цироз печінки в поєднанні 3 дисбіозом кишечнику, проведено оцінку функціонального стану печінки, клінічних проявів печінкової енцефалопатії, нейропсихометричних тестів, мікробіоценозу кишечнику та включено до комплексного лікування препарат лакто- та біфідобактерій і гідрогель метилкремнієвої кислоти. Включення до комплексного лікування даних препаратів призводило до вірогід-

Вступ. Як і в Україні, так і в усьому світі спостерігається тенденція до росту захворювань печінки, їх прогресуючого перебігу з формуванням цирозу печінки (ЦП). Цироз печінки разом із хронічним гепатитом (ХГ) посідають 2-4-те місця серед причин госпіталізації та втрати працездатності осіб віцком 20-60 років. В Україні за останні 10 років захворюваність на ЦП зросла на 75,6 \%, поширеність цирозу печінки - на 59,6 \% $[5,8,12]$. Одним із найбільш частих ускладнень ЦП є печінкова енцефалопатія (ПЕ), симптомокомплекс зворотних нейропсихічних порушень, що виникає при гепатоцелюлярній недостатності i/ або портокавальному шунтуванні, основними клінічними проявами якого є зміни особистості, розлади інтелекту і мови, розвиток тривожнодепресивних станів, порушення свідомості і сну, а в тяжких випадках - кома і смерть хворого [14]. Щорічно більше 20 \% хворих на ЦП вперше відмічають маніфестацію ПЕ, яка в 35-40 \% випадків характеризується розгорнутою клінічною симптоматикою, нерідко 3 летальним кінцем. Виживання хворих протягом першого року після маніфестації клінічно вираженої ПЕ досягає лише $42 \%$, прогресивно зменшуючись протягом наступних трьох років до $21 \%$. Домінуючу роль у розвитку ПЕ посідає аміак та меркаптани. Аміак утворюється в товстій кишці із продуктів білкового розпаду під дією амонієгенної мікрофлори, надходить по ворітній вені у печінку, де в нормі більша його частина включається в орнітиновий цикл, кінцевим продуктом якого є сечовина. Аміак, що не включився в цикл сечовини, захоплюється перивенозними гепатоцитами, в яких із різних аміно- і кетокислот і аміаку під дією глутамінсинтетази утворюється глутамін. Ці два механізми служать для запобігання попадання токсичного аміаку в системний кровотік [2, 11]. При печінковій енцефалопатії швидкість метаболізму аміаку та інших токсинів у печінці значно знижується. Крім того, аміак попадає у загальний кровотік по портокавальних анастомозах, при цьому він виключається із печінкового метаболізму. Неіонізований аміак в астроцитах під дією глутамін-синтетази сприяє збільшенню пулу

(C) I.M. Гавриш, 2014

18 но кращої редукції суб'єктивних і об'єктивних проявів цирозу, вираженості функціонально-біохімічних синдромів, проявів печінкової енцефалопатії.

Ключові слова: цироз печінки, печінкова енцефалопатія, дисбіоз кишечнику, препарат лакто- та біфідобактерій, гідрогель метилкремнієвої кислоти.

глутаміну - осмотично активної речовини, зміна концентрації якої призводить до розвитку набряку глії, набряку головного мозку і розвитку симптомокомплексу ПЕ [7, 13, 16]. Аміак посилює проникність гематоенцефалічного бар'єра, підвищуючи концентрацію ароматичних амінокислот у тканинах головного мозку, зокрема триптофану, що призводить до синтезу несправжніх нейротрансмітерів, які заміщують справжні нейромедіатори (допамін, норадреналін) і тим самим перешкоджають нормальній нейропередачі. Зниження синтезу фізіологічних допаміну та норадреналіну призводить до неадекватної нейротрансмісії та розвитку ПЕ. Несправжні нейротрансмітери можуть синтезуватися не тільки у ЦНС. Їх джерелом також є мікрофлора кишечнику, і при печінково-клітинній недостатності або портосистемних шунтах вони попадають у ЦНС, стаючи причиною ПЕ [15].

Отже, незважаючи на сучасні досягнення гепатології, проблеми своєчасної діагностики й оптимізації лікування початкових проявів ПЕ, як і раніше, залишаються надзвичайно актуальними. $\mathrm{y}$ цьому аспекті важливим $\epsilon$ комплексний та своєчасний підхід до діагностики ПЕ вже на початкових етапах іï формування з метою профілактики прогресування уражень ЦНС із використанням психометричних тестів. Також важливе значення має включення в комплексне медикаментозне лікування хворих на ЦП ефективних засобів детоксикації з урахуванням основних патогенетичних механізмів формування ПЕ [10].

Мета дослідження. Корекція печінкової енцефалопатії у хворих на ЦП в поєднанні з дисбіозом кишечнику шляхом застосування препарату лакто- та біфідобактерій і гідрогелю метилкремнієвої кислоти.

Матеріал і методи. Обстежено 65 хворих на ЦП алкогольної та вірусної етіології та 15 практично здорових осіб, які склали контрольну групу. Обстежені були пацієнтами гастроентерологічного відділення МКЛ № 1 м. ІваноФранківська. За статтю всі обстежені розподілялися так: 16 осіб - жінки $(24,6 \%)$ та 49 осіб чоловіки $(75,4$ \%). Середній вік пацієнтів - 
$54,8 \pm 1,2$ року, при цьому переважали пацієнти працездатного віку, що підкреслює не тільки медичне, а й соціальне значення проблеми діагностики і лікування ЦП. Тривалість захворювання коливалася від 1 до 10 років (середня тривалість $4,38 \pm 2,38)$. Всім пацієнтам, залученим у дослідження, після ознайомлення і підписання ними інформованої згоди проводилося загальноклінічне та лабораторно-інструментальне обстеження. У діагностиці ЦП використовували класифікацію Міжнародної робочої групи і Всесвітнього конгресу гастроентерологів у Лос-Анджелесі в 1994 році та МКХ-10. Діагноз цирозу печінки ставили на основі скарг хворих, анамнезу захворювання, лабораторних даних, даних УЗД печінки та селезінки, езофагогастродуоденоскопічного дослідження. Діагноз ЦП верифіковано за даними клінічного (скарги, анамнез, фізикальні дані) та лабораторно-інструментального обстеження згідно з Наказом МО3 України № 271 від 13.06.2005 p.

Діагностика вірусного ЦП включала визначення маркерів вірусного гепатиту В і С згідно 3 алгоритмами діагностики. Алкогольне ураження печінки діагностували на основі даних про щоденне вживання алкоголю в дозі не менше 50 г у перерахунку на етанол упродовж 2-5 років, результатів опитувальника Європейської гастроентерологічної асоціації (CAGE), клінічних і біохімічних проявів ураження печінки, виявлення стигм хронічного алкоголізму, наявність у частини осіб характерних лабораторних даних (анемія, лейкопенія, тромбоцитопенія, підвищення рівня амінотрансфераз) [4, 6].

У процесі дослідження визначали основні сироватково-біохімічні печінкові синдроми: цитолізу, холестазу, печінково-клітинної недостатності та мезенхімально-запальної реакції. Активність амінотрансфераз визначали за методом Райтмана-Френкеля, рівень загального та прямого білірубіну визначали за методом Ендрашека. Також оцінювали показники тимолової проби та протромбінового індексу, вивчали в динаміці рівень аміаку та сечовини сироватки крові. Печінкову енцефалопатію оцінювали за тестом зв'язку чисел - тест Рейтона та астериксисом («хлопаючий тремор») $[1,3]$. Вивчення видового і кількісного складу мікрофлори вмісту товстої кишки проводили методом посіву десятиразових розведень на стандартний набір селективних та диференційно-діагностичних поживних середовищ для виділення аеробних і анаеробних мікроорганізмів [9].

Розподіл пацієнтів на групи провели за використаними підходами до їх лікування. Пацієнтів розподілили на дві групи. Пацієнти 1-ї групи (33 особи отримували базове лікування згідно 3 клінічним протоколом із надання медичної допомоги хворим на цироз печінки (Наказ МО3 України від 13.06.2005 р. №271). Пацієнти 2-ї групи (32 особи) на тлі базової терапії отримували препарат лакто- та біфідобактерій і гідрогель метилкремнієвої кислоти. Використали вітчизняні пре- парати: препарат лакто- та біфідобактерій «Біфілакт екстра» («Аріадна», м. Одеса) та гідрогель метилкремнієвої кислоти - «Ентеросгель» («Креома-Фарм», м. Київ). Контрольну групу сформували 15 практично здорових осіб.

Статистичну обробку результатів досліджень проводили за допомогою програм «Statistica for Windows v. 7.1». Вірогідність різниці кількісних показників визначали за допомогою $\mathrm{t}$ критерію Стьюдента. Різницю між показниками вважали статистично вірогідною при р $<0,05$.

Результати дослідження та їх обговорення. У клінічній картині обстежених пацієнтів переважали прояви астеновегетативного синдрому. Наявність астеновегетативного синдрому спостерігалась у 91,5 \% осіб та проявлялася загальною слабкістю, низькою працездатністю, підвищеною втомлюваністю, психоемоційною лабільністю, головним болем та порушенням сну. Після проведеного лікування всі пацієнти відчували покращення самопочуття, проте відмічено, що в пацієнтів 2-ї групи спостерігалося більш швидке усунення астеновегетативного синдрому- на п'ять днів раніше, ніж у пацієнтів 1-ї групи.

У процесі лікування відмічена позитивна динаміка оцінених нами показників мови, сну, координації, критики, настрою та уваги. Вірогідно кращу динаміку показників досягнуто в пацієнтів 2-ї групи, які крім базової терапії отримували препарат лакто- та біфідобактерій та гідрогель метилкремнієвої кислоти (табл. 1).

Динаміка біохімічних показників у процесі лікування відображена в табл. 2 .

Згідно $з$ даними табл. 2, після проведеного лікування спостерігали достовірне покращання біохімічних показників крові в обох групах, проте відмічено вірогідно кращу динаміку цих показників у пацієнтів 2-ї групи. Зокрема на тлі проведеного лікування рівень аміаку достовірно знизився у 2,1 раза (до 43,7 $\pm 2,6$ кммоль/л) у пацієнтів 2-ї групи та в 1,6 раза (до $54,8 \pm 2,1$ кммоль/л) у пацієнтів 1-ї групи відповідно $(\mathrm{p}<0,05)$.

Отже, динаміка біохімічних показників сироватки крові в пацієнтів 2-ї групи є вірогідно кращою, ніж у групі порівняння. Це свідчить про недостатній ефект від проведення базисної терапії та потребує включення до комплексної терапії препарату лакто- та біфідобактерій і гідрогелю метилкремнієвої кислоти.

Як видно з табл.3, після проведеного лікування відмітили покращення показників виконання тесту Рейтона. До лікування тест Рейтона виконували пацієнти 2-ї групи в середньому за

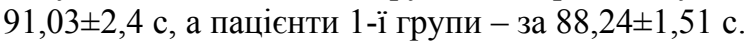
Після проведеного лікування у пацієнтів 2-ї групи спостерігали достовірне зниження часу вико-

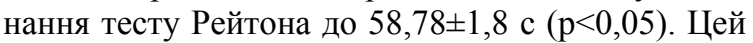
показник $\epsilon$ кращим, ніж у групі порівняння $(69,42 \pm 1,76 \mathrm{c})$.

Після проведеного лікування в 2-й групі достовірно зросла кількість пацієнтів, у яких астериксис не спостерігався (21 $(65,6 \%), \mathrm{p}<0,05)$. 
Таблиця 1

Динаміка клінічних проявів печінкової енцефалопатії у процесі лікування

\begin{tabular}{|c|c|c|c|c|}
\hline \multirow{2}{*}{ Порушення } & \multicolumn{2}{|c|}{ Перша група $(\mathrm{n}=33)$} & \multicolumn{2}{|c|}{ Друга група $(\mathrm{n}=32)$} \\
\cline { 2 - 5 } & До лікування & $\begin{array}{c}\text { Після } \\
\text { лікування }\end{array}$ & До лікування & $\begin{array}{c}\text { Після } \\
\text { Лікування }\end{array}$ \\
\hline Мова & $30(90,9 \%)$ & $14(42,4 \%)$ & $29(90,6 \%)$ & $6(18,8 \%)$ \\
\hline Сон & $33(100 \%)$ & $10(30,3 \%)$ & $32(100 \%)$ & $7(21,9 \%)$ \\
\hline Координація & $28(84,8 \%)$ & $8(24,2 \%)$ & $29(90,6 \%)$ & $4(12,5 \%)$ \\
\hline Критичне мислення & $31(93,9 \%)$ & $20(60,6 \%)$ & $28(87,5 \%)$ & $16(50 \%)$ \\
\hline Настрій & $33(100 \%)$ & $9(27,3 \%)$ & $32(100 \%)$ & $5(15,6 \%)$ \\
\hline Увага & $33(100 \%)$ & $10(30,3 \%)$ & $32(100 \%)$ & $6(18,8 \%)$ \\
\hline
\end{tabular}

Примітка. У дужках вказано відсоток до загальної кількості осіб у групі; n - кількість хворих

Таблиця 2

Динаміка біохімічних показників у хворих на цироз печінки

\begin{tabular}{|c|c|c|c|c|c|}
\hline \multirow{2}{*}{ Біохімічні показники } & \multirow{2}{*}{$\begin{array}{c}\text { Контроль, } \\
\mathrm{n}=15\end{array}$} & \multicolumn{2}{|c|}{ Перша група $(\mathrm{n}=33)$} & \multicolumn{2}{|c|}{ Друга група $(\mathrm{n}=32)$} \\
\cline { 3 - 6 } & & До лікування & Після лікування & До лікування & Після лікування \\
\hline Заг.білірубін, мкмоль/л & $11,65 \pm 0,39$ & $52,93 \pm 5,43$ & $36,90 \pm 3,07^{*}$ & $51,83 \pm 5,92$ & $26,11 \pm 2,44^{*}$ \\
\hline Прямий, мкмоль/л & $1,44 \pm 0,16$ & $23,97 \pm 3,26$ & $14,84 \pm 2,04^{*}$ & $25,05 \pm 4,43$ & $8,45 \pm 1,37^{*}$ \\
\hline Тимолова проба., од. & $2,25 \pm 0,09$ & $7,29 \pm 0,83$ & $4,02 \pm 0,29^{*}$ & $4,54 \pm 0,39$ & $3,52 \pm 0,22^{*}$ \\
\hline АлАТ, ммоль/л•год & $0,45 \pm 0,01$ & $1,31 \pm 0,12$ & $0,73 \pm 0,05^{*}$ & $1,35 \pm 0,26$ & $0,61 \pm 0,05^{*}$ \\
\hline АсАТ, ммоль/л•год & $0,33 \pm 0,01$ & $0,85 \pm 0,09$ & $0,58 \pm 0,04^{*}$ & $0,70 \pm 0,07$ & $0,41 \pm 0,03^{*}$ \\
\hline Заг. білок, г/л & $74,79 \pm 0,51$ & $69,44 \pm 1,74$ & $71,62 \pm 1,21$ & $69,83 \pm 1,24$ & $73,44 \pm 1,20^{*}$ \\
\hline Аміак, кммоль/л & $23,5 \pm 2,3$ & $89,5 \pm 3,5$ & $54,8 \pm 2,1^{*}$ & $92,5 \pm 8,6$ & $43,7 \pm 2,6^{*}$ \\
\hline Сечовина, ммоль/л & $3,23 \pm 0,26$ & $7,5 \pm 0,68$ & $5,9 \pm 0,53^{*}$ & $7,1 \pm 0,77$ & $3,8 \pm 0,24$ \\
\hline Протромбіновий & $88,25 \pm 0,55$ & $69,96 \pm 1,70$ & $80,64 \pm 0,95^{*}$ & $74,9 \pm 1,89$ & $85,37 \pm 0,99^{*}$ \\
\hline індекс (ПІ), \% & & & & & \\
\hline
\end{tabular}

Примітка. Вірогідність різниці показників до і після лікування: * - p<0,05; n - кількість хворих

Таблиця 3

Динаміка тесту Рейтона в процесі лікування, $\mathrm{M} \pm \mathrm{m}$

\begin{tabular}{|c|c|c|c|c|c|}
\hline \multirow{3}{*}{$\begin{array}{c}\text { Тест } \\
\text { Рейтона, с }\end{array}$} & \multirow{2}{*}{$\begin{array}{c}\text { Контроль, } \\
\mathrm{N}=15\end{array}$} & \multicolumn{2}{|c|}{ Перша група ( n=33 ) } & \multicolumn{2}{|c|}{ Друга група (n = 32) } \\
\hline & & До лікування & $\begin{array}{c}\text { Після } \\
\text { лікування }\end{array}$ & До лікування & $\begin{array}{c}\text { Після } \\
\text { лікування }\end{array}$ \\
\hline & $28,53 \pm 0,34$ & $88,24 \pm 1,51$ & $69,42 \pm 1,76^{*}$ & $91,03 \pm 2,4$ & $58,78 \pm 1,8 *$ \\
\hline
\end{tabular}

Примітка. Вірогідність різниці показників до і після лікування: * - $<0,05 ; \mathrm{n}$ - кількість хворих

Таблиця 4

\section{Динаміка ступеня астериксису в процесі лікування}

\begin{tabular}{|c|c|c|c|c|}
\hline \multirow{2}{*}{$\begin{array}{c}\text { Ступінь } \\
\text { астериксису }\end{array}$} & \multicolumn{2}{|c|}{ Перша група $(\mathrm{n}=33)$} & \multicolumn{2}{c|}{ Друга група $(\mathrm{n}=32)$} \\
\cline { 2 - 5 } & До лікування & Після лікування & До лікування & Після лікування \\
\hline 0 & $5(15,2 \%)$ & $10(30,3 \%)$ & $4(12,5 \%)$ & $21(65,7 \%)$ \\
\hline 1 & $16(48,5 \%)$ & $20(60,6 \%)$ & $17(53,1 \%)$ & $9(28,1 \%)$ \\
\hline 2 & $8(24,2 \%)$ & $2(6,1 \%)$ & $6(18,8 \%)$ & $1(3,1 \%)$ \\
\hline 3 & $4(12,1 \%)$ & $1(3,0 \%)$ & $5(15,6 \%)$ & $1(3,1 \%)$ \\
\hline
\end{tabular}

Примітка. У дужках вказано відсоток до загальної кількості осіб у групі; n - кількість хворих 
Таблиця 5

Динаміка мікрофлори кишечнику у хворих на цироз печінки в процесі лікування, М \pm m

\begin{tabular}{|c|c|c|c|c|c|}
\hline \multirow[b]{2}{*}{$\begin{array}{c}\text { Показник, } \\
\text { КУО/г }\end{array}$} & \multirow[b]{2}{*}{ Контроль, $\mathrm{n}=15$} & \multicolumn{2}{|c|}{ Перша група $(\mathrm{n}=33)$} & \multicolumn{2}{|c|}{ Друга група (n=32) } \\
\hline & & $\begin{array}{c}\text { До } \\
\text { лікування } \\
\end{array}$ & $\begin{array}{c}\text { Після } \\
\text { лікування } \\
\end{array}$ & $\begin{array}{c}\text { До } \\
\text { лікування } \\
\end{array}$ & $\begin{array}{c}\text { Після } \\
\text { лікування } \\
\end{array}$ \\
\hline Bifidobacterium $(<\operatorname{Ig} 8,0$ КУО/г) & $9,58 \pm 0,53$ & $5,23 \pm 1,21$ & $7,71 \pm 3,1$ & $4,27 \pm 0,48$ & $9,10 \pm 0,41^{*}$ \\
\hline Lactobacillus (<Ig 8,0 КУО/Г) & $8,47 \pm 0,39$ & $3,64 \pm 1,26$ & $6,41 \pm 0,81^{*}$ & $3,41 \pm 0,45$ & $7,45 \pm 0,82^{*}$ \\
\hline $\begin{array}{c}\text { - E.coli } 3 \text { норм. фермент. активні- } \\
\text { стю }(<\operatorname{Ig} 7,0 \text { КУО/г) }\end{array}$ & $7,53 \pm 0,31$ & $3,47 \pm 0,66$ & $5,56 \pm 1,21$ & $3,18 \pm 0,35$ & $6,84 \pm 0,69 *$ \\
\hline - E.coli lac - & 0 & $5,42 \pm 0,25$ & $2,35 \pm 0,18^{*}$ & $5,44 \pm 0,34$ & $0^{*}$ \\
\hline - E.coli hly $+(>10 \%)$ & 0 & $4,77 \pm 0,06$ & $3,72 \pm 0,15^{*}$ & $4,41 \pm 1,14$ & $0^{*}$ \\
\hline $\begin{array}{c}\text { Staph.aureus } \\
(>\operatorname{Ig~} 3,0 \mathrm{KУO} / \Gamma)\end{array}$ & $3,32 \pm 0,21$ & $5,90 \pm 1,43$ & $2,21 \pm 0,74^{*}$ & $4,75 \pm 1,22$ & $3,27 \pm 0,26$ \\
\hline Ентерококи $(<\operatorname{Ig} 6,0$ КУО/г) & $9,71 \pm 0,39$ & $2,64 \pm 1,07$ & $4,47 \pm 0,18^{*}$ & $2,69 \pm 0,56$ & $6,12 \pm 0,41 *$ \\
\hline Candida $(>\operatorname{Ig} 4,0$ КУО/г) & 0 & $4,95 \pm 1,8$ & $3,3 \pm 0,88$ & $4,53 \pm 1,21$ & $1,82 \pm 1,4^{*}$ \\
\hline $\begin{array}{c}\text { Умовно-патогенні ентеробактерії } \\
\text { (УПЕ) (>Ig 5,0 КУО/г) }\end{array}$ & 0 & $7,16 \pm 0,23$ & $5,64 \pm 0,56^{*}$ & $7,50 \pm 0,32$ & $2,60 \pm 0,60 *$ \\
\hline
\end{tabular}

Примітка. Вірогідність різниці показників до і після лікування * - p<0,05; n - кількість хворих

Цей показник кращий, ніж у групі порівняння (табл. 4).

Отже, враховуючи зазначене можна стверджувати, що регрес ПЕ більш виражений у пацієнтів 2-ї групи, які крім базисної терапії приймали препарат лакто- та біфідобактерій і гідрогель метилкремнієвої кислоти.

Динаміка мікрофлори кишечнику в процесі лікування хворих на ЦП висвітлена в табл. 5.

За даними табл. 5 після проведеного лікування титри біфідо- та лактобактерій зросли в 1-й групі в 1,5 та 1,8 раза відповідно, а в 2-й групі - у 2,1 та 2,2 раза, $\mathrm{p}<0,05$. У пацієнтів 1-ї групи після лікування зберігалася наявність лактозонегативної та гемолітичної E.coli в кількості 2,35 $\pm 0,18$ КУО/Г та $3,72 \pm 0,15 \mathrm{KУО/Г} \mathrm{відповідно,} \mathrm{чого} \mathrm{не}$ спостерігали в пацієнтів 2-ї групи, $\mathbf{p}<0,05$. Титр дріжджоподібних грибків зменшився в 1,5 раза в 1-й групі та в 2,5 раза в пацієнтів 2-ї групи відповідно, а титр УПЕ зменшився в 1,3 раза в 1-й групі та в 2,9 раза в пацієнтів 2-ї групи відповідно, $\mathrm{p}<0,05$.

За даними кореляційного аналізу, виявили статистично значущі кореляційні зв'язки переважно середньої сили між кількістю УПЕ, лактобактерій, біфідобактерій та часом виконання тесту зв'язку чисел $(\mathrm{r}=+0,5213, \mathrm{p}<0,05, \mathrm{r}=-0,3365$, $\mathrm{p}<0,05, \mathrm{r}=0,3575, \mathrm{p}<0,05$ відповідно). Наявність кореляційних зв'язків між кількістю УПЕ, лактобактерій, біфідобактерій та часом виконання тесту зв'язку чисел дає підстави припустити їхню участь як у розвитку, так і в прогресуванні печінкової енцефалопатії у хворих на ЦП.

\section{Висновок}

Включення до комплексного лікування обстежених хворих на цироз печінки препарату лакто- та біфідобактерій і гідрогелю метилкремнієвої кислоти призводило до вірогідно кращої редукції суб'єктивних і об'єктивних проявів ци- розу, вираженості функціонально-біохімічних синдромів, покращання когнітивних функцій, суттєвому внормуванню мікробіоценозу в обстежених осіб, що проявлялося збільшенням титру біфідо- та лактобактерій, E.coli 3 нормальною ферментативною активністю, суттєвим зниженням титру умовно-патогенних ентеробактерій та дріжджоподібних грибків. Застосування препарату лакто- та біфідобактерій і гідрогелю метилкремнієвої кислоти на тлі базової терапії призводило до регресу печінкової енцефалопатії, про що свідчать покращання мови, сну, уваги, координації рухів, критики, мислення, настрою, а також результати психометричних тестів.

Перспективи подальших досліджень. Ширше впровадження в лікувальну практику препарату лакто- та біфідобактерій і гідрогелю метилкремнієвої кислоти в індивідуально підібраному дозуванні у хворих на цироз печінки в поєднанні з дисбіозом кишечнику за умов різної вираженості патологічних порушень.

\section{Література}

1. Бабак О.Я. Современные возможности коррекции печеночной энцефалопатии у пациентов с цирозом печени / О.Я. Бабак, Е.В. Колесникова, Т.Е. Козырева // Сучас. гастроентерол. - 2010. - № 4 (54). - С. 71-76.

2. Богомолов П.О. Коррекция печеночной энцефалопатии: патофизиологические основы применения пребиотиков / П. О. Богомолов, А.В. Петраков, О.С. Кузьмина // Трудный пациент. - 2006. - Т. 4, № 7. - С. 37-41.

3. Буеверов А.О. Печеночная энцефалопатия: клинические варианты и терапевтические возможности / А.О. Буеверов // Рос. ж. гастроэнтерол., гепатол. и колопроктол. - 2003. - № 5. - С. 46-52.

4. Євстігнєєв І.В. Хронічні хвороби печінки: проблеми прогресування цирозу / І.В. Євстігнєєв, В.I. Чорний, В.I. Капшученко // Сучас. гастроентерол. - 2008. № 2 (40). - C. 103-107.

5. Звягинцева Т.Д. Хронические диффузные заболевания печени: патогенетические подходы к лечению / Т.Д. Звягинцева, С.В. Глущенко // Здоров'я України. 2010. - № 1. - С. 46-47. 
6. Лобанець Н.В. Розробка клініко - лабораторного комплексу для підтвердження алкогольної етіології у хворих на цироз печінки / Н.В. Лобанець // Вісн. наук. досліджень. - 2010. - № 2. - С. 109-112.

7. Маев И.В. Оценка эффективности комплексной терапии печеночной энцефалопатии у больных циррозом печени / И.В. Маев, Е.С. Вьючнова, Е.Г. Лебедева // Клин. мед. - 2002. - № 5. - С. 42-45.

8. Нейко Є.М. Сучасні погляди на цироз печінки / Є.М. Нейко, О.А. Шаповал // Гал. лікар. вісник. 2006. - T. 13, № 4. - С. 140-142.

9. Дисбактеріоз кишечнику: клініка, діагностика, шляхи корекції / М.В. Патратій, В.П. Пішак, В.О. Калугін [та ін.]. - Чернівці, 2006. - 112 с.

10. Передерій В.Г. Сравнительная эффективность применения гепатопротекторов при хронических диффузных заболеваниях печени / В.Г. Передерій, В.В. Чернявський, В.П. Шипулин // Сучас. гастроентерол. 2008. - № 3. - C. 81-83.

11. Пошегорова Н.В. Портальна енцефалопатія при гепаторенальному синдромі / Н.В. Пошегорова, С.С. Сір- чак, Х.В. Футько // Експерим. і клін. мед. - 2010. № 2. - C. 99-102.

12. Самогальська О.Є. Цироз печінки: сучасний стан проблеми / О.Є. Самогальська, Н.В. Карпенко // Сім. мед. - 2009. - № 2. - С. 6-8.

13. Селиверстов П. Взаимоотношения печени и кишечника на фоне дисбаланса микрофлоры толстой кишки / П. Селиверстов, В. Радченко, И. Сафроненкова // Врач. - 2009. - № 10. - С. 27-31.

14. Сірчак Є.С. Вплив гепадифу на амінокислотний спектр сироватки крові у хворих на цироз печінки / Є.C. Сірчак, Н.В. Пошегорова, В.I. Русин // Експерим.та клін. мед. - 2009. - № 3. - С. 98-102.

15. Харченко Н.В. Печінкова енцефалопатія: особливості медикаментозного та дієтичного лікування / Н.В. Харченко, Г.А. Анохіна, Н.Д. Опанасюк // Сучас. гастроентерол. - 2010. - № 6 (56). - С. 68-72.

16. Randolph C. Neuropscyhological assessment of hepatic encephalopathy: ISHEN practice guidelines / C. Randolph, R. Hilsabeck, A. Kato // Liver Int. - 2009. Vol. 29. - P. 629-635.

\section{КОРРЕКЦИЯ ПЕЧЕНОЧНОЙ ЭНЦЕФАЛОПАТИИ У БОЛЬНЫХ ЦИРРОЗОМ ПЕЧЕНИ В СОЧЕТАНИИ С ДИСБИОЗОМ КИШЕЧНИКА}

\section{И.М. Гаврищ}

Резюме. Обследовано 65 больных циррозом печени в сочетании с дисбиозом кишечника, проведена оценка функционального состояния печени, клинических проявлений печеночной энцефалопатии, нейропсихометрических тестов, микробиоценоза кишечника и включено в комплексное лечение препарат лакто- и бифидобактерий и гидрогеля метилкремниевой кислоты. Включение в комплексное лечение данных препаратов приводило к достоверно лучшей редукции субъективных и объективных проявлений цирроза, выраженности функционально - биохимических синдромов, проявлений печеночной энцефалопатии.

Ключевые слова: цирроз печени, печеночная энцефалопатия, дисбиоз кишечника, препарат лакто-и бифидобактерий, гидрогель метилкремниевой кислоты.

\section{CORRECTION OF HEPATIC ENCEPHALOPATHY IN PATIENTS WITH LIVER CIRRHOSIS IN COMBINATION WITH INTESTINAL DYSBIOSIS}

\section{I.M. Havrysh}

Abstract. 65 patients with liver cirrhosis combined with intestinal dysbiosis have been examined; an assessment of the functional state of the liver, clinical manifestations of hepatic encephalopathy, neuropsychometric tests, intestinal microbiota has been carried out; Lactobacillus and Bifidobacterium as well as Methylsiliconic acid hydrogel were included into the complex treatment. Inclusion of these drugs in the complex treatment resulted in significantly better reduction of subjective and objective signs of cirrhosis, severity of functional and biochemical syndromes, symptoms of hepatic encephalopathy.

Key words: liver cirrhosis, hepatic encephalopathy, intestinal dysbiosis, medication of Lactobacillus and Bifidobacterium, Methylsiliconic acid hydrogel.

SHEE "Ivano-Frankivsk National Medical University"

Рецензент - проф. О.І. Федів

Buk. Med. Herald. - 2014. - Vol. 18, № 1 (69). - P. 18-22

Надійшла до редакції 04.12.2013 року

(C) I.М. Гавриш, 2014 